\title{
Development of Social Studies Learning Outcomes with Tajhin Peddhis-Based Etnopedagogy Approach
}

\author{
Emi Tipuk Lestari ${ }^{1}$, Saiful Bahri ${ }^{2}$ \\ DOI: 10.35445/alishlah.v13i3.977
}

\begin{abstract}
Article Info Abstract
Keywords:

Ethno

pedagogy;

Social Studies;

Tajhin Pheddis

The purpose of this study was to describe social studies learning outcomes with an Ethno pedagogy approach based on the tajhin pheddis tradition. The research method is classroom action research with the Spiral Model from Kemmis and Taggart. In general, four stages are usually passed, namely: Planning, Acting, Observing, and Reflecting. The subjects or informants are social studies teachers and Class VII students at Madrasah Tsanawiyah. This study's techniques and data collection tools were observation and interview techniques. Student learning outcomes have increased between cycle 1 and cycle 2 . The increase in learning outcomes can be seen from the average cycle 1 of 62,5 . The average value in cycle II has increased by 79,5 , while the average presentation of completeness in the cycle This II increased to $80 \%$ of students who completed above the KKM score. Based on the average value and the percentage of classical learning completeness, it can be concluded that social studies learning with an ethnopedagogic approach based on the tajhin pheddis tradition can improve student learning outcomes in social studies subjects. Learning with an ethnopedagogic approach through the tajhin tradition pheddis can be an approach in social studies learning that is meaningful learning. It is shown that the study results indicate an increase in student learning outcomes at MTs AL-Ikhlas Kuala Mandor B.
\end{abstract}

\begin{abstract}
Abstrak
Tujuan penelitian ini adalah mendeskripsikan hasil belajar IPS dengan pendekatan etnopedagogik berbasis tradisi tajhin pheddis. Adapun metode penelitian ini adalah penelitian tindakan kelas (classroom action research) dengan Model Spiral dari Kemmis dan Taggart yang secara garis besar terdapat empat tahapan yang biasa dilalui, yaitu : Planning, Acting, Observing dan Refleksi. Subjek atau informanya adalah guru IPS dan siswa Kelas VII di Madrasah Tsanawiyah. Teknik dan alat pengumpul data yang digunakan dalam penelitian ini adalah teknik observasi dan teknik wawancara. Hasil belajar siswa mengalami peningkatan antara siklus 1 dan siklus 2. Peningkatan hasil belajar itu dapat dilihat dari rataorata siklus 1 sebesar 62,5 . Nilai rata-rata pada siklus II telah mengalami kenaikan sebesar 79, 5, sedangkan rata -rata presentasi ketuntasan pada siklus II ini meningkat menjadi $80 \%$ murid yang tuntas diatas nilai KKM. Berdasarkan nilai rata-rata dan presentase ketuntasan belajar klasikal maka dapat disimpulkan bahwa pembelajaran IPS dengan pendekatan etnopedagogik berbasis tradisi tajhin pheddis dapat meningkatkan hasil belajar siswa pada mata pelajaran IPS Kelas VII. Pembelajaran dengan pendekatan etnopedagogik melalui tradisi tajhin pheddis dapat menjadi suatu pendekatan dalam pembelajaran IPS yang bersifat meaningfull learning. Hal ini diperlihatkan bahwa hasil penelitian menunjukan bahwa terjadi peningkatan hasil belajar siswa di MTs AL-Ikhlas Kuala Mandor B.
\end{abstract}

Kata kunci:

Etnopedagogi;

Pembelajaran

IPS; Tajhin Pheddis

\footnotetext{
${ }^{1}$ IKIP PGRI Pontianak, Pontianak, Kalimantan Barat, Indonesia Email: tipoeklestari@gmail.com

2 IKIP PGRI Pontianak, Pontianak, Kalimantan Barat, Indonesia

Email: bangipoelponty@gmail.com
}

Vol.13 (3) December, 2021

Received: August 16, 2021; Received in revised form: October 27, 2021; Accepted: November 23, 2021; Available online: December 28, 2021. This is an open access article under a Creative Commons Attribution-NonCommercial-ShareAlike 4.0 International License. 


\section{INTRODUCTION}

Education today has almost lost its identity as a structured process to make every student become a complete human being. Huntington (2015: 37) states that amid a climate of globalization, education is needed both as a support for national identity, as well as a problem solver for local, regional, national, and global problems. Soemantri (2001:215) that Social Studies Education aims to realize advanced education in the social sciences and humanities and prepare students to become good citizens. The competencies and objectives of social studies learning are to deliver, guide, and develop the potential of students to become good citizens and citizens of the world. Social studies at the school level aim to prepare students as citizens who have knowledge, skills, attitudes, and values that can be used to solve personal problems or social problems and the ability to make decisions and participate in various social activities to become good citizens (Sapriya, 2009).

While having a positive effect, globalisation also has a negative effect, as evidenced by the erosion of indigenous wisdom values; the complexity of issues concerning the character or morality of students in this country has become a source of concern for all segments of the nation. This moral or character crisis is characterized by apathy (ignorance) toward the surrounding social environment, diminished empathy for others, and apathy toward indigenous wisdom (culture) values. In society, the phenomenon in MTs AlIkhlas Kuala Mandor B students is referred to as social pathology. Social studies education, without a doubt, plays a critical role in shaping the nation's personality, human quality, and Indonesian society in general. Nonetheless, given the phenomenon of national and state life in Indonesia, the success of social studies education in instilling values of national and state life in the younger generation is debatable (Misnah, 2016).

Social studies learning must transfer knowledge and transfer value to participants. This is by the goal of social studies education, which is to shape students to become good citizens in their lives. For this reason, teachers must make students interested in learning social studies lessons that require values so that learning is more meaningful (Nur Rahmah 2013, 44). One of the interesting ways of learning social studies is that social studies learning must be related to social conditions, the environment, and the values of local wisdom that exist in an area. Local wisdom can be sourced from the culture of the community in a certain locality. Local wisdom can be used as a learning resource. This happens because local wisdom is a culture that needs to be maintained to maintain the characteristics of an area. Implementing learning based on local cultural wisdom, or called ethnopedagogic-based social studies learning, is effective when integrated into subjects (Asmani, 2012:9-10). The ethnopedagogic nature, according to Alwasilah, views that education cannot be separated from social and cultural aspects. Education is deliberative in the sense that society transmits and perpetuates the idea of a good life that comes from fundamental community beliefs about the nature of the world, knowledge, and values (Alwasilah, 2009:16).

Social science education and local wisdom are a combination that should not be separated (Anwar, 2015; Isaac, 2013; Misnah, 2018). The essence of social studies learning is to integrate the values of local wisdom and the nation's noble values. If social studies learning does not integrate local cultural values, it allows students as the nation's next generation to be uprooted from their cultural roots. The characteristics of the Indonesian nation in the eyes of the international community who are admired for their cultural diversity gradually fade and even disappear. Education is an institution that provides cultural values and social values for or a source of educational teaching materials. Culture can colour the form of education that can be used as a tool for the progress of the nation and state. Cultural values or essences possessed by regional cultures or ethnic groups that contain and have educational value can provide models and learning methods that are by the personality and character of the nation and can be used by the community to build Indonesian people from one generation to the next (Simanjuntak, 2014).

Cultural values that exist around students will be able to arouse students' curiosity in studying social studies material. It will also affect student learning outcomes in a lesson. In this regard, researchers are interested in presenting a pearl of local wisdom that is packaged in Ethno pedagogybased social studies learning in social studies learning. The researcher's local wisdom is the tradition of 
tajhin pheddis. This tradition lives in the daily life of the Madurese community, which must be passed on to the younger generations in the MTs Al-Ikhlas Kuala Mandor B environment.

Tajhin Pheddis in Madura implies various noble messages. In addition to preserving the Selamatan tradition, Tajhin Pheddis, with various compositions in it, carries an important message, harmony in diversity. Land products combined with marine products. All melted together in a pot bound by the starch that glues all together. Tajhin Pheddis is a tradition of maintaining solidarity among human beings. Serving various flavours of food followed by sending each other to relatives and neighbours is called the Ter-Ater tradition. Ter-ater is part of the tradition of the Madurese community which implies sharing the taste of food (rice or cake) for neighbors, relatives or parties who deserve to be given ter-ater. Ter-ater tajhin pheddis is one way to maintain horizontal relations between residents and strengthen social harmony (social integration) in Kuala Mandor B. Every citizen gets comfort and peace in community life. Build and strengthen social solidarity to strengthen community resilience based on emotional attachment and kinship ties. Strengthen and strengthen the adhesiveness of a social relationship in order to prevent and eliminate potential conflicts and avoid friction in society. The Tajhin Pheddis tradition that requires social integration values, can be used as a learning resource in social studies learning in class VIII junior high school at MTs Al Ikhlas Kuala Mandor B Kubu Raya.

The findings reinforce this (Karsiwan et al., 2017). Social studies learning based on local wisdom values is able to provide an alternative learning process that is interesting, fun, and at the same time challenging for students. Social studies learning based on the themes of local wisdom is very helpful in the learning process at school. Through this social studies learning process based on local wisdom values, students are expected to be able to develop ideas, ideas, creativity in thinking, and scientific argumentation through a learning process that can place students as learning actors.

Meanwhile, research (Sani, DM; Sukarmin; Suharno, 2020) states that teachers must provide appropriate learning media to assess student competence by national learning objectives during the Covid-19 pandemic. The purpose of this study was to determine and analyze the needs of teachers in developing learning media in the form of electronic modules (e-modules) based on local wisdom with the type of information seeking to empower critical thinking skills and student character values in learning. The results showed that 95\% of teachers needed the development of e-module media based on finding information on the type of local wisdom to empower students' critical thinking skills and character values during the Covid-19 pandemic.

Education in this era of globalization ideally remains associated with students' lives so that learning will be truly valuable (meaningful learning). Learning materials related to norms or values in each subject need to be developed, made explicit, linked to the context of everyday life. Thus, local wisdom is also a study in social studies learning. Learning is not only at the cognitive level but touches on internalization and real practice in students' daily lives in society. For this reason, the purpose of this article is to describe social studies learning planning with an ethnopedagogic approach through the tajhin pheddis tradition, explain the implementation of social studies learning with an ethnopedagogic approach through the tajhin pheddis tradition, and explain the learning outcomes of Class VII students at MTs Al-Ikhlas Kuala foreman B in learning. Social Studies with an ethnopedagogic approach through the tajhin pheddis tradition.

\section{METHOD}

The research method used is classroom action research with the Spiral Model from Kemmis and Taggart. In general, four stages are usually passed: a. Develop a Plan of Action (Planning), b. Implementation of Action (Acting),: c. Observing (Observing), and d. Reflecting (Wiriaatmdja, 2009: 66). The subject or the informant is a social studies teacher and class VII students at MTs Swasta Al Ikhlas Kuala Mandor B Kubu Raya. The data collection technique used in this study is a direct observation technique to teachers and students, direct communication techniques, namely interviewing teachers and students related to the planning, implementation, and evaluation of learning, as well as assessment techniques related to student learning outcomes. Data collection tools are adapted to data 
collection techniques, namely observation guides, interview guides, and learning outcomes test questions. Data analysis techniques In this study, using interactive analysis according to Milles and Huberman (Sugiyono, 2009), namely 1) Collecting good data obtained from observations, interviews, and learning outcomes tests, 2) data obtained then data reduction, 3) after data is reduced then the data obtained is presented in the form of a display of data presentation in the form of descriptions, tables, and even pictures and 4) drawing conclusions (verification) which are presented straightforwardly. The analysis is carried out continuously from the beginning of data collection to the verification process from the beginning of the study until the research is completed.

\section{FINDINGS AND DISCUSSION}

Based on the results of observations made in this study, starting with planning activities, pre-cycle activities and continued with corrective actions in cycle one and gradually in cycle 2, where the implementation period of pre-cycle activities and cycle 1 at the end of early August 2021 for 2 weeks and continued in cycle 2 in the third week of August 2021. The results obtained are as follows: Based on the results of observational learning outcomes show that using ethnopedagogic-based social studies learning through tajhin pheddis in learning cycle 1 from observation 1, namely learning about social interaction: understanding, terms, and forms (accommodation, cooperation, assimilation) that are integrated with the tradition of tajhin pheddis. After going through the learning outcomes test in the form of multiple-choice questions with the KKM standard of 70, the data obtained from student learning outcomes who have very good abilities with a score (81-100) in understanding social interaction are 2 students (10\%), who have good abilities with a score of (70). -80) totalling 4 students (20\%), who have sufficient ability with a score (60-69) totalling 4 students (20\%), who have less ability with a score (40-59) totalling 8 students (40\%), and who have the very poor ability with a value of (o39) amounted to 2 students (10\%). Students who have very low grades because do not master the learning material. However, from the data analysis, the values in the first cycle classically have not reached the value of $70 \%$. While in cycle 2 from observers 1 and 2 students who have very good abilities with grades (81-100) in understanding social interaction, there are 2 students (10\%), who have the good ability with a value of (70-80) are 4 students (20\%), who have sufficient ability with a value of (60-69) are 4 students (20\%), those who have less ability with a score of (40-59) are 8 students (40\%), and those who have the very poor ability with a value of (0-39) are 2 students (10\%). Students who have very low grades because do not master the learning material. However, from the data analysis, the values in the first cycle classically have reached a value of $70 \%$. The increase in the value of the IPS above can be seen in the following table 1.

Table 1. Comparison of Qualifications of Learning Outcomes in Cycles 1 and 2

\begin{tabular}{ccccccc}
\hline No & Grade qualification & Cycle 1 & Percentage & Cycle II & Percentage & Evaluation \\
\hline 1 & $81-100$ & 2 & $10 \%$ & 6 & $30 \%$ & Very good \\
\hline 2 & $70-80$ & 4 & $20 \%$ & 10 & $50 \%$ & good \\
\hline 3 & $60-69$ & 4 & $20 \%$ & 2 & $10 \%$ & Enough \\
\hline 4 & $40-59$ & 8 & $40 \%$ & 2 & $10 \%$ & Not enough \\
\hline 5 & $0-39$ & 2 & $10 \%$ & - & - & Very less \\
\hline
\end{tabular}

Source; Researcher 2021

The data above illustrates that the mastery of social interaction related to the tradition of tadjin pedhis has increased and has reached the competency standard of the KKM set in schools of 70\%. In this second cycle of research, students classically have been able to master the theoretical concept of social inequality by looking at the tradition of tadjin pedhis properly and correctly. The results of the assessment and observation in the second cycle on learning the material of social interaction in space and its influence on social, economic, and cultural life in values and norms as well as socio-cultural institutions in class VII students of MTs Al Ikhlas Kuala Mandor B have improved very well. The attitude of students in participating in learning activities on social interaction materials in space and their 
influence on social, economic, and cultural life in values and norms as well as socio-cultural institutions is carried out using an inquiry learning model with the inquiry method that is experiencing a change in a positive direction.

Meanwhile, observations about student attitudes when learning have increased at each meeting, especially in cycle II. The activities of students during the learning process were observed by researchers by paying attention to positive attitudes consisting of 4 aspects and negative attitudes consisting of 5 aspects. The results of observations of students' positive attitudes in cycles I and II can be seen from the following table 2 .

Table 2. Observations of students' positive attitudes in cycles I and cycle II

\begin{tabular}{|c|c|c|c|c|c|c|c|c|c|}
\hline \multirow[t]{3}{*}{ No } & \multirow[t]{3}{*}{ Student Activity } & \multicolumn{4}{|c|}{ cycles I } & \multicolumn{4}{|c|}{ cycle II } \\
\hline & & \multicolumn{2}{|c|}{ Meeting 1} & \multicolumn{2}{|c|}{ Meeting 2} & \multicolumn{2}{|c|}{ Meeting 1} & \multicolumn{2}{|c|}{ Meeting 2} \\
\hline & & $\begin{array}{l}\text { Frequen } \\
\text { cy }\end{array}$ & $\%$ & $\begin{array}{l}\text { Frequen } \\
\text { cy }\end{array}$ & $\%$ & $\begin{array}{l}\text { Frequen } \\
\text { cy }\end{array}$ & $\%$ & $\begin{array}{l}\text { Frequen } \\
\text { cy }\end{array}$ & $\%$ \\
\hline 1 & $\begin{array}{l}\text { Students collect assignments } \\
\text { about the Tajhin Pheddis } \\
\text { tradition that is still being } \\
\text { carried out in their } \\
\text { environment }\end{array}$ & 6 & 30 & 7 & 35 & 12 & 60 & 17 & 85 \\
\hline 2 & $\begin{array}{l}\text { Enthusiastic students ask } \\
\text { about learning materials }\end{array}$ & 3 & 15 & 4 & 20 & 14 & 70 & 16 & 80 \\
\hline 3 & $\begin{array}{l}\text { Students actively answer } \\
\text { questions from the teacher }\end{array}$ & 3 & 15 & 4 & 20 & 10 & 50 & 16 & 80 \\
\hline 4 & $\begin{array}{l}\text { Students work hard on } \\
\text { assignments }\end{array}$ & 6 & 30 & 8 & 40 & 12 & 60 & 17 & 85 \\
\hline
\end{tabular}

Source; Researcher 2021

Based on the data above, it can be concluded that ethnopedagogic-based social studies learning through the tajhin peddhis tradition can improve the learning outcomes of class VII students at MTs Al Ikhlas Kuala Mandor B. Next, the teacher explains examples of the tajhin peddhis tradition, which are examples of social interactions that exist in their environment. Ethnopedagogic-based learning with the use of the tajhin peddhis tradition is effective learning in inculcating social values such as mutual cooperation and integration or unity among them. From the problems given, students are expected to be able to identify, collect information, and provide opinions about tajin peddhis. Some students seemed enthusiastic about paying attention to the explanation given by the teacher, but some other students still looked busy themselves. Seeing that some students were still busy alone during the explanation given by the teacher. The teacher asked the students about the tajin peddhis procession which was related to social interaction material. Students seem still confused by the explanation given by the teacher, this is because the teacher is too fast in providing an explanation. Students' understanding of the material of social interaction in space and its influence on social, economic, and cultural life in values and norms as well as socio-cultural institutions using the Ecopedagogy approach. The ethnopedagogy approach through the tradition of tajhin peddhis as a critical pedagogue is very much in line with social studies learning. Social studies learning seeks to build students' ecological intelligence to think critically about local problems and issues (Supriatna, 2007; Diacopoulos, 2020).

The three materials above can be used as a source of social studies learning because social studies is an integration of social and humanities disciplines. In contrast, in schools, social studies as educational programs are selected from the disciplines of history, geography, economics, sociology, anthropology, archaeology, psychology, politics, philosophy, religion, and the law of the NCSS (Abbas, 2015). Social studies learning with sustainable and transformative concepts wants students who can interpret social studies learning to benefit themselves and the environment. For this reason, in ethnopedagogic-based social studies learning through the tajhin peddhis tradition, teachers can include richer sources other than textbooks, namely social studies learning resources must be developed from the school environment, living environment, students' social experiences, and electronic media (Sapriya, 2009). 
The tadjin pedhis tradition of ethnopedagogical social studies education As a means of reducing verbalism among students, particularly those in class VII at MTs Al Ikhlas Kuala Mandor B. Connecting the deconstructed classroom to the outside world is possible through the use of a social studies learning strategy based on the tadjin pedhis tradition, which begins with the closest environment and works outward. As a result, Ecopedagogy incorporates learning activities that connect the classroom to the real world to help students understand sustainability (Sapriya, 2009). Social studies education aims to instil in students an awareness of society's symptoms and social problems. Meanwhile, students must be able to make connections between various fields of social science and the symptoms and problems they are studying in order to come up with a solution. Subiyakto et al., 2017; Syaharuddin et al., 2020) (Abbas, 2013; Subiyakto et al., 2017; Syaharuddin et al., 2020).

According to research (Bahri, 2020), baumatahutn is a human act endowed with noble characteristics that must be preserved in accordance with their nature. This tradition values indigenous wisdom, which is brought to life through ethnopedagogy-based social investigation learning. Additionally, religious characteristics, rules, obligations, social considerations, and natural characteristics all factor into intelligence assessment. As a result, its application in Social Studies Learning through Ethno Pedagogy produces positive results. Similar research has discovered that game-based learning can improve student achievement and attitudes toward learning (Syaharuddin et al., 2021). According to Lestari (2018), ethnopedagogic-based social studies learning through planned plans and actions and social studies learning through the use of the environment as a learning resource can positively affect students' success in participating in the learning process. The same study was also discovered in research (Bahri 2020) using the ter-ater tradition's values approach, which was able to increase the value of student care. Students' enthusiasm is evident when they are assigned to participate in the most exciting activities available in their environment. Additionally, students can direct their attention to the material presented. Environmental-based social studies education is also found in research (Lestari, 2019). Pantulak Temple is a form of acculturation for the Dayak, Malay, Madurese, and Chinese tribes, resulting in cultural diversity and inter-tribal peace that has endured to this day. In multicultural social studies education, the Pantulak Temple serves as a source of learning that is appropriate for the material and social circumstances of multi-ethnic students at SMP N 3 Sungai Ambawang.

The delivery of social values in learning, especially social studies, links learning materials with traditions that are still carried out by the community where the students live. In online learning, this is learning that involves more students or is called inquiry learning. Ethnopedagogic-based social studies learning using the tadjin pedhis tradition is meaningful learning. This is by Piaget's opinion (Sanjaya, 2006: 196). This knowledge will be meaningful if it is sought and found by students themselves, not the results of other people's notifications and found by students themselves, not the results of other people's notifications, including teachers. In this theory, students need to be accustomed to solving problems, finding something useful for themselves, and struggling with ideas. Teachers are not required to provide all knowledge to students. Students must construct knowledge in their own minds. The essence of this theory is the idea that students must find and transform complex information into other situations, and if desired, the information becomes their own.

In planning the implementation of ethnopedagogic-based social studies learning through the tajhin pheddis tradition, the teacher designs a social science learning implementation plan (RPP) which includes the tajhin pheddis tradition. The purpose of making lesson plans is so that students have a good understanding and use of the knowledge possessed by students so that conceptual, factual, and values in the tajhin pheddis tradition can be absorbed perfectly. In addition, the integration material can be understood and understood so that learning is more meaningful. The basic values behind the tajhin pheddis tradition as the basic characteristics of the Madurese community are the values of mutual cooperation, unity, or integration, students can perfectly absorb caring as a provision to become good citizens aware of social procedures or called good citizenship. This goal is by the main objective of social studies learning, namely 
Social Studies Taught as citizenship Transmission, which is to develop good citizens in accordance with the norms that have been accepted standardly in their country (Alma, 2013:43-44).

In making the learning program plan, the tradition of tajhin pheddis was integrated into social studies subjects to introducing the values of character education in the subject. The aim is to provide students with an awareness of the importance of these values and to internalize these values into the behaviour of students in everyday life through the learning process. Basically, learning activities, in addition to making students master the targeted competencies (materials), are also designed to make students recognize, realize/care, and internalize values and turn them into behaviour (Grabe \& Grabe; 2000).

Every subject in SMP or MTs actually contains materials related to character education. The development of character education values in each subject can be done by integrating the values of character education into the appropriate basic competencies (KD) contained in the Content Standards (Permendiknas No. 22 of 2006). The number of KD in each subject that can be integrated with character education values is certainly different, some are many, and some are few. Furthermore, the basic competencies that can be integrated with character education values are developed in the syllabus and learning implementation plan (RPP).

Social studies education learning strategies above the appropriate learning strategies to achieve social studies learning objectives are critically dialogical, direct experiences, collaborative and cooperative strategies. Such a learning strategy emphasizes three areas of learning, namely; cognitive, affective, and psychomotor. This is in line with what was stated by Kirschenbaum (in Setiawan, 2013; 67), that the social studies-citizenship education aspect includes; knowledge, appréciation, critical thinking skills, communication skills, cooperation skills, and conflict resolution skills. Kirschenbaum further stated that these aspects require a comprehensive approach that includes; inculcation, modelling, facilitation, and skills development (Embi, 2009). Kwe and Kean's (2014) research findings implied that PBI is a more viable and effective alternative instruction to teaching culture to the students and their foreign language teachers.

For this reason, the implementation of ethnopedagogic-based social studies learning through the tajhin pheddis tradition can be carried out in grade VII MTs in the first semester with basic competencies. Analyzing social interactions in space and their effects on social, economic, and cultural life in values and norms as well as socio-cultural institutions. While the materials are 1) Social interaction: understanding, terms, and forms (accommodation, cooperation, assimilation), 2) The influence of social interaction on the formation of social, cultural, economic, educational, and political institutions. 3) Social institutions: definitions, types, and functions (economy, education, culture, and politics). Character values that can be raised are Appreciating and living honest behaviour, discipline, responsibility, caring (tolerance, cooperation), polite, confidence, in interacting effectively with the social and natural environment within reach of association and existence.

\section{CONCLUSION}

This study found that ethnopedagogic-based social studies learning through the tajhin pedhis tradition could improve the learning outcomes of grade VII students at MTs Al Ikhlas Kuala Mandor B for the academic year 2021-2022. Ethnopedagogic-based learning using the tajhin pedhis tradition effectively inculcates social values such as cooperation and integration or unity among them. This can be seen from the increase in student learning outcomes of Class VII MTs Al-Ikhlas from cycle 1 to cycle 2 , namely the average value in the first cycle is 62,5 . This value is still below the KKM value of 70, while the average presentation of completeness in the cycle. There are still only $30 \%$ of students who complete above the KKM score. From the data above, the value in the first cycle classically has not reached the value of $70 \%$. And the average score in the second cycle has increased by 79.5 , while the average completeness presentation in the second cycle has increased to $80 \%$ of students who complete above the KKM score. From the problems given, students are expected to be able to identify, collect information, and provide opinions about tajhin pedhis. Through the tradition of tajin pedhis as a critical 
pedagogue, the Ethno pedagogy approach is very suitable for social studies learning because teachers can include richer sources other than textbooks, namely social studies learning resources must be developed from the school environment, residential environment, existing social experiences.

\section{REFERENCES}

Abbas, E. W. (2015). Pendidikan IPS Berbasis Kearifan Lokal. WAHANA Jaya Abadi. http://eprints.ulm.ac.id/4172/

Abbas, E. W. (2013). Mewacanakan Pendidikan IPS (Cetakan Kedua). WAHANA Jaya Abadi. http://eprints.ulm.ac.id/5481/

Alma, Buchari, Harlasgunawan Ap. (2003). Hakekat Studi Sosial : the Nature of Social Studies). Bandung: Alfabeta.

Alwasilah, A. C., Suryadi, K., Tri Karyono. (2009). Etnopedagogi: Landasan Praktek Pendidikan dan Pendidikan Guru. Bandung: Kiblat Buku Utama.

Anwar, Senen, (2015). Pendidikan IPS Berbasis Budaya. The Poceeding Of Internasional Seminar On The Ethnopedagogy Unlam Press

Asmani, J. M. (2012). Pendidikan Berbasis Keunggulan Lokal. Yogyakarta: Diva Press

Bahri, S., \& Lestari, E. T. (2020). Implementasi Nilai Peduli Sosial Melalui Tradisi Ter-Ater Masyarakat Suku Madura Pada Pembelajaran Ilmu Pengetahuan Sosial Di MTs Al Iklas Kuala Mandor B. Refleksi Edukatika: Jurnal Ilmiah Kependidikan, 10(2), 187-198.

Bahri, S., \& Lestari, E. T. (2020). The Baumatahutn traditional values of Dayak Kanayatn communities in implementing social studies based on ethnopedagogy. In Emerging Perspectives and Trends in Innovative Technology for Quality Education 4.0 (pp. 15-18). Routledge: Taylor \& Francis Group.

Diacopoulos, M. M., \& Crompton, H. (2020). A systematic review of mobile learning in social studies. $\begin{array}{lllll}\text { Computers } \quad \& \quad \text { Education, } & 103911 .\end{array}$ https://doi.org/https://doi.org/10.1016/j.compedu.2020.103911

Embi, Mohamed Amin \& Amelia Abdullah. (2009). Meaning learning in a networked learning environment. In Mohamed Amin Embi (ed). (2009). Computer-Mediated Communication: Pedagogical Implications of Malaysian Research Findings. Shah Alam: Karisma Publications.128-141.

Fatiya Nur Azizah. (2020). Strategi Meaningfull Learning dalam Proses Belajar Mengajar Pendidikan Agama Islam di Tengah Pandemi Covid-19. Journal of Islamic Education Research | Vol. 1 No. o3 Desember (2020) dalam file://C:/Users/HP/Downloads/51-Article\%20Text-251-1-1020201230.pdf

Fukuyama, F (2000). Social Capital and Civil Society. International Monetary Fund Working Paper, WP/oo/74, 1-8. In Elinor Ostrom and T.K. Ahn. 2003. Foundation of Social Capital. Massachusetts: Edward Elgar Publishing Limited.

Grabe, M., \& Grabe, C. (2000). Integrating the Internet for Meaningful Learning. Boston: Houghton Mifflin Co.

Huntington, S. P. (2015). The clash of civilizations? In Conflict After the Cold War: Arguments on Causes of War and Peace. American Enterprise Institute. https://doi.org/10.4324/9781003060963-50

Isaac, Eshum. (2013). Appraisal Of Colleges Of Education Social Studies Curriculum Vis-a-vis The Jjunior High School (JHS) Social Studies Curriculum Implementation In Ghana.Journal Of Education and Practive. ISSN 2222- 1737(Paper) ISSN-288X(Online). Vol. 4,2013.

Karsiwan, Pujiati, dan Rufaidah. (2017). Pembelajaran IPS Berbasis Nilai-Nilai Kearifan Lokal Pada Siswa Smk Farmasi Cendikia Farma Husada. Dalam jurnal Jurnal Penelitian Humano, Vol. 8 No. 1 Edisi Juni 2017. http://download.garuda.ristekdikti.go.id/article.php?article

Kean, A. C., \& Kwe, N. M. (2014). Meaningful learning in the teaching of culture: The project-based learning approach. Journal of Education and Training Studies, 2(2), 189-197. doi:10.11114/jets.v2i2.270

Lestari, E. T., Bahri, S., \& Purmintasari, Y. D. (2019). Value Historis Situs Kelenteng Pantulak Sebagai Sumber Belajar IPS Berbasis Pendidikan Multikulture Kelas VII di SMPN 3 Sungai Ambawang. SOCIA: Jurnal Ilmu-Ilmu Sosial, 16(2), 133-148.

Lestari, E.T., Astuti, T.M.P., Utomo, C.B. and Priyanto, A.S., (2018). Social Studies Learning Based on Ethnopedagogic through Social Relations of Dayak and Chinese Ethnics in Making Integration: 
A Study in Pontianak West Kalimantan, Indonesia. Proceedings of the International Conference on Science and Education and Technology 2018 (ISET 2018): Atlantis Press

Misnah. (2018). Philosophy of Hituwu and Katuwua as Learning Sources In Teaching Social Science Subject Among Kulawi Indigenous People. Advances in Social Science, Education and Humanities Research, Volume 174/Doi:10.2991/ice-17.2018.14)

Misnah. (2016). Kearifan Lokal Sebagai Sumber Pembelajaran Sejarah Lokal. the Proceeding Of Internasional Seminar On Ethnopedagogy. 2016 Lambung Amangkurat University: Unlam Press

Nur Rahmah. (2013). Belajar Bermakna Ausubel. Dalam JUrnal Al Khawarizmi Jurnal Pendidikan Matematika dan Ilmu Pengetahuan Alam, Vol 1 Maret 2013, 44

Sani, D M; Sukarmin; Suharno. (2020). The Needs Analysis For The Development Of Electronic Learning Module (E-Module) Based On Local Wisdom Information Search In Senior High Schools' Physics Online Learning During COVID-19 Pandemic dalam Journal of Physics: Conference Series; Bristol Vol. 1796, Iss. 1, (Feb 2021). DOI:10.1088/1742-6596/1796/1/012020 Sanjaya, Wina.(2006). Strategi Pembelajaran. Jakarta: Kencana Prenada Media Group

Sapriya. (2009). Pendidikan IPS. Bandung: PT. Remaja Rosdakarya.

Setiawan, Deni., (2013). Reorientasi Tujuan Utama Pendidikan Ilmu Pengetahuan Sosial Dalam Perspektif Global. Dalam jurnal JUPIIS VOLUME 5 Nomor 2, dalam file://C:/Users/HP/Downloads/1115-1899-1-PB.pdf

Simanjuntak, B. A., Panjaitan, A. P., Darmawan, A., Maharani, Purba., I. R., Rachmad, Y., dan Simanjuntak, R. (2014). Landasan Teori dan Refleksi Korelasi Kebudayaan dan Pendidikan. hlm. 1-53 dalam Bungaran Antonius Simanjuntak (edt.) Korelasi Kebudayaan dan Pendidikan: Membangun Pendidikan Berbasis Budaya Lokal. Jakarta: Yayasan Pustaka Obor Indonesia

Subiyakto, B., Syaharuddin, S., \& Rahman, G. (2017). Nilai-Nilai Gotong Royong Pada Tradisi Bahaul Dalam Masyarakat Banjar Di Desa Andhika Sebagai Sumber Pembelajaran IPS. Vidya Karya, 31(2). https://doi.org/10.20527/jvk.v31i2.3993

Sugiyono. (2009). Metode Penelitian Kuantitatif, Kualitatifdan $R \& D$. Bandung. Alfabeta.

Supriatna, Nana, dkk. (2007). Pendidikan IPS di Sekolah Dasar. Bandung: UPI Press.

Supriatna, Nana, dkk. (2017). Ecopedagogy: Membangun Kecerdasan Ekologis dalam Pembelajaran IPS. Bandung: PT. Remaja Rosdakarya.

Syaharuddin, S., Rahman, A. M., \& Fitriyani, R. (2020). Utilization Of Social Community as Learning Resources On Social Studies. The Kalimantan Social Studies Journal, 1(1), 18- 24. https://doi.org/10.20527/kss.v1i1.1253

Syaharuddin, S., Mutiani, M., Handy, M. R. N., Abbas, E. W., \& Jumriani, J. (2021). Building Students' Learning Experience in Online Learning During Pandemic. Al-Ishlah: Jurnal Pendidikan, 13(2), 979-987.

Waterwroth. (2007). Social Studies and Project. Washington : National Commision on Social Studies in The Schools h 5 .

Wiriaatmadja, Rochiati. (2006). Metode Penelitian Tindakan Kelas Untuk Meningkatkan Tenaga Guru dan Dosen. Bandung: Pt Remaja Rosdakarya. 
Al- Ishlah: Jurnal Pendidikan, December 2021, 13 (3), Pages 2309-2318

Emi Tipuk Lestari, Saiful Bahri

This page is intentionally left blank 